\title{
ПЕРСПЕКТИВИ РЕАЛІЗАЦІЇ ЕЛЕКТРОННИХ ВИДАНЬ НА УКРАЇНСЬКОМУ РИНКУ
}

() В. О. Польова, Я. Є. Сошинська, к.і.н., доцент, нтуУ «КПІ», Київ, Україна

В статье рассматриваются перспективы реализации электронных изданий на украинском рынке, базируясь на анализе макро- и микросреды украинского электронного книжного магазина «Bookland.net.ua». Оценка факторов, анализ возможностей и угроз проводится по методике SWOT-анализа.

The article is devoted to prospects of the e-texts trading in the Ukrainian market on the basis of the analysis macroand micro- environment of Ukrainian electronic bookshop «Bookland.net.ua». Evaluation factors, opportunities and threats made by the method of SWOT-analysis.

\section{Постановка проблеми}

Швидкі темпи розвитку інтелектуальних технологій та рівня інформаційного забезпечення спричиняють зростання потреб споживачів щодо швидкості отримання інформації, доступності, зручності їі використання. Створення глобальної віртуальної мережі Інтернет відкрило нові можливості для отримання й обміну інформацією. З'явилась електронна торгівля, яка $€$ прибутковим каналом збуту різноманітної продукції.

3 розвитком інформаційних технологій з'явилось явище і поняття «електронне видання», тобто версія книги в електронному (цифровому) форматі. Електронне видання також стало об'єктом купівлі-продажу в мережі Інтернет. На сьогодні реалізацією електронного контенту на українському книжковому ринку займається український електронний книжковий магазин «Bookland.net.ua», який функціонує з кінця 2008 року. Під- приємство розвивається швидкими темпами, про що свідчить зростання кількості продажів (закачок) електронного контенту на 85 тис. одиниць та темп приросту у 233,3 \% у 2010 році, порівняно $з$ попереднім роком. Саме на прикладі даного підприємства доцільно розглядати перспективи реалізації електронних видань на книжковому ринку України.

\section{Аналіз попередніх досліджень}

Дослідження поняття «електронне видання» та «електронна книга» в понятійній системі документознавства, класифікацію електронних видань, визначення їх характеристик проводили такі вчені як Гіляревський Р. С. [1-3], Шрайберг Я. Л. та Земсков А. І. [4, 5], Воройський Ф. С. [6], Кушнаренко Н. М. [7], Бєловицька А. О. [8], Швецова-Водка Г. М. [9], Антопольський А. Б. [10], Бушуєв С. В. [11], Гресь А. М. [12], Чикунов І. М. [13], Оста- 
пова І. В. та Широнов В. А. [14], Тимошик М. [15] та ін. Окремі публікації таких авторів, як Мамонтова М. С. [16], Меджибовська Н. С. [17], Чернишов О. [18] розглядали проблеми електронної книги в Україні. Разом з тим, відсутнє комплексне дослідження, яке присвячене питанням реалізації електронного книжкового контенту і об'єднує такі складники як характеристика товару, аналіз цільової аудиторії і споживчого попиту, ціноутворення, технологічні аспекти продажу і доставки товару та ін.

\section{Мета роботи}

Мета даної публікації полягає в обґрунтуванні перспектив реалізації електронних видань на українському ринку як нового напряму книжкового бізнесу і книготоргівлі.

\section{Результати проведених досліджень}

Для вивчення основних тенденцій на ринку цифрового книжкового контенту було обрано діяльність компанії «Bookland.net. иа». Аналіз факторів, що впливають на реалізацію даного виду товару, здійснено за методикою SWOT-аналізу. Таким чином, було проведено оцінку зовнішнього і внутрішнього середовища підприємства, проаналізовано його макросередовище і безпосереднє оточення. Розглянемо отримані результати дослідження, представлені у таблиці 1.

Таблиця 1

Оцінка факторів макросередовища

\begin{tabular}{|c|c|c|c|c|}
\hline $\begin{array}{c}\text { Група } \\
\text { факторів }\end{array}$ & Фактори & Прояв (стан фактора) & $\begin{array}{c}\text { Характер } \\
\text { впливу } \\
\text { на підпр. } \\
(+/-)\end{array}$ & $\begin{array}{c}\text { Оцінка } \\
\text { фактора } \\
\text { впливу, у } \\
\text { балах }\end{array}$ \\
\hline \multirow{6}{*}{ Економічні } & $\begin{array}{l}\text { Розвиток електронної } \\
\text { комерції в Україні }\end{array}$ & $\begin{array}{l}\text { Галузь недостатньо сфор- } \\
\text { мована, проте розви- } \\
\text { вається }\end{array}$ & + & 3 \\
\hline & $\begin{array}{l}\text { Розвиток торгівлі елек- } \\
\text { тронними книгами }\end{array}$ & $\begin{array}{l}\text { Активно пропонуються і } \\
\text { реалізуються пристрої для } \\
\text { читання електронних ви- } \\
\text { дань, книгарні займаються } \\
\text { продажем електронних } \\
\text { видань на компакт-дисках }\end{array}$ & + & 3 \\
\hline & $\begin{array}{l}\text { Розвиток електронної } \\
\text { торгівлі електронними } \\
\text { книгами }\end{array}$ & $\begin{array}{l}\text { Для України ще не є дуже } \\
\text { поширеним явищем }\end{array}$ & + & 3 \\
\hline & $\begin{array}{l}\text { Вартість електронних } \\
\text { видань }\end{array}$ & $\begin{array}{l}\text { Вартість електронних книг } \\
\text { нижча за друковані аналоги }\end{array}$ & + & 3 \\
\hline & $\begin{array}{l}\text { Вартість пристроїв для } \\
\text { читання електронних } \\
\text { книг }\end{array}$ & $\begin{array}{l}\text { Висока вартість електрон- } \\
\text { них рідерів гальмує про- } \\
\text { цес поширення електрон- } \\
\text { них видань }\end{array}$ & - & 2 \\
\hline & $\begin{array}{l}\text { Рівень податкових ста- } \\
\text { вок }\end{array}$ & $\begin{array}{l}\text { Відсутні спеціальні податко- } \\
\text { ві ставки, Податковий ко- } \\
\text { декс } 2010 \text { року змінив спро- } \\
\text { щену систему оподаткуван- } \\
\text { ня для електронної комер- } \\
\text { ції, відсутні пільги }\end{array}$ & - & 2 \\
\hline
\end{tabular}


Закінчення табл. 1

\begin{tabular}{|c|c|c|c|c|}
\hline $\begin{array}{l}\text { Група } \\
\text { факторів }\end{array}$ & Фактори & Прояв (стан фактора) & $\begin{array}{c}\text { Характер } \\
\text { впливу } \\
\text { на підпр. } \\
(+/-)\end{array}$ & $\begin{array}{c}\text { Оцінка } \\
\text { фактора } \\
\text { впливу, у } \\
\text { балах }\end{array}$ \\
\hline & $\begin{array}{l}\text { Рівень доходів насе- } \\
\text { лення }\end{array}$ & $\begin{array}{l}\text { Невисокий рівень доходів } \\
\text { населення, порівняно із } \\
\text { розвинутими країнами, } \\
\text { може спричинити те, що } \\
\text { вторинні потреби задо- } \\
\text { вольняються недостатньо }\end{array}$ & - & 2 \\
\hline Політичні & $\begin{array}{l}\text { Рівень політичної } \\
\text { стабільності }\end{array}$ & $\begin{array}{l}\text { Низький рівень політичної } \\
\text { стабільності негативно } \\
\text { відображається на стані } \\
\text { економіки }\end{array}$ & - & 2 \\
\hline \multirow[b]{2}{*}{ Правові } & $\begin{array}{l}\text { Стан законодавчих } \\
\text { актів, які регулюють } \\
\text { електронну комерцію }\end{array}$ & $\begin{array}{l}\text { Відсутні спеціальні законо- } \\
\text { давчі акти, які регулюють } \\
\text { електронну комерцію }\end{array}$ & + & 1 \\
\hline & $\begin{array}{l}\text { Стан законодавчих } \\
\text { (нормативних) актів, } \\
\text { які визначають поняття } \\
\text { «електронне видання» }\end{array}$ & $\begin{array}{l}\text { В } 2010 \text { році введено в дію } \\
\text { ДСту 7151:2010 «Видання } \\
\text { електронні. Основні види } \\
\text { та вихідні відомості» }\end{array}$ & + & 1 \\
\hline \multirow{3}{*}{$\begin{array}{l}\text { Демо- } \\
\text { графічні }\end{array}$} & $\begin{array}{l}\text { Чисельність користу- } \\
\text { вачів мережі Інтернет в } \\
\text { Україні }\end{array}$ & Динамічно зростає & + & 3 \\
\hline & $\begin{array}{l}\text { Чисельність покупців } \\
\text { електронних магазинів } \\
\text { в Україні }\end{array}$ & Зростає & + & 3 \\
\hline & $\begin{array}{l}\text { Чисельність користу- } \\
\text { вачів електронними ви- } \\
\text { даннями в Україні }\end{array}$ & Поступово зростає & + & 3 \\
\hline \multirow[b]{2}{*}{ НТП } & $\begin{array}{l}\text { Рівень технічного за- } \\
\text { безпечення населення }\end{array}$ & Достатній & + & 2 \\
\hline & $\begin{array}{l}\text { Реалізація вітчизняних } \\
\text { пристроїв для читання } \\
\text { електронних видань }\end{array}$ & $\begin{array}{l}\text { Електронні рідери вироб- } \\
\text { ляються за кордоном або } \\
\text { в співпраці з іноземними } \\
\text { компаніями }\end{array}$ & - & 1 \\
\hline \multirow[t]{2}{*}{ Природні } & $\begin{array}{l}\text { Використання сирови- } \\
\text { ни для виготовлення } \\
\text { електронного видання }\end{array}$ & $\begin{array}{l}\text { Збереження природних } \\
\text { ресурсів }\end{array}$ & + & 2 \\
\hline & $\begin{array}{l}\text { Забруднення навко- } \\
\text { лишнього середовища }\end{array}$ & $\begin{array}{l}\text { Електронні видання } є \text { еко- } \\
\text { логічно чистими }\end{array}$ & + & 1 \\
\hline \multirow{3}{*}{$\begin{array}{l}\text { Соціаль- } \\
\text { но-куль- } \\
\text { турні }\end{array}$} & $\begin{array}{l}\text { Рівень читання в Ук- } \\
\text { раїні }\end{array}$ & $\begin{array}{l}\text { Невисока популярність чи- } \\
\text { тання }\end{array}$ & - & 2 \\
\hline & $\begin{array}{l}\text { Рівень інформатизації } \\
\text { суспільства }\end{array}$ & $\begin{array}{l}\text { Рівень розвитку інфор- } \\
\text { маційного суспільства Ук- } \\
\text { раїни нижчий від показ- } \\
\text { ників Європи, США та ін. } \\
\text { країн }\end{array}$ & - & 2 \\
\hline & $\begin{array}{l}\text { Традиція читання елек- } \\
\text { тронних видань }\end{array}$ & З'явилась і розвивається & + & 3 \\
\hline
\end{tabular}


Оцінка характеру (спрямованості) впливу на підприємство здійснювалася за такою шкалою:

+1 бал - позитивний вплив;

- 1 бал - негативний вплив.

Оцінка ступеня впливу фактора на підприємство здійснювалася експертним шляхом за такою оцінною шкалою:

3 бали - сильний вплив;

2 бали - помірний вплив;

1 бал - слабкий вплив;
0 балів - відсутній вплив.

Отже, в таблиці 1 відображено фактори макросередовища, які мають певний вплив на основну комерційну діяльність компанії «Bookland.net.ua». Heобхідно визначити, які з них $€$ можливостями, а які загрозами у розвитку торгівлі цифровим книжковим контентом та розглянути можливі варіанти відповідних дій підприємства.

Таблиця 2

Аналіз можливостей і загроз макросередовища

\begin{tabular}{|c|c|c|}
\hline Фактори & $\begin{array}{c}\text { Ступінь впли- } \\
\text { ву фактора на } \\
\text { підприємство, } \\
\text { бали }\end{array}$ & $\begin{array}{c}\text { Можливі варіанти відповідних дій } \\
\text { підприємства }\end{array}$ \\
\hline \multicolumn{3}{|c|}{ Можливості } \\
\hline $\begin{array}{l}\text { Розвиток електронної } \\
\text { комерції в Україні }\end{array}$ & 3 & $\begin{array}{l}\text { Зарубіжна практика свідчить про перспек- } \\
\text { тиви розвитку електронної комерції, тому } \\
\text { її варто розвивати в Україні }\end{array}$ \\
\hline $\begin{array}{l}\text { Розвиток торгівлі елек- } \\
\text { тронними книгами }\end{array}$ & 3 & $\begin{array}{l}\text { Успішна реалізація електронних видань на } \\
\text { зовнішніх носіях показала, що попит на та- } \\
\text { кий продукт є, а реалізація електронних } \\
\text { видань через мережу Інтернет спрощує } \\
\text { процес купівлі }\end{array}$ \\
\hline $\begin{array}{l}\text { Розвиток електронної } \\
\text { торгівлі електронними } \\
\text { книгами }\end{array}$ & 3 & $\begin{array}{l}\text { Підприємство зайняло нову нішу на ук- } \\
\text { раїнському ринку книжкової торгівлі }\end{array}$ \\
\hline $\begin{array}{l}\text { Вартість електронних } \\
\text { видань }\end{array}$ & 3 & $\begin{array}{l}\text { Електронні видання в ціновому аспекті ма- } \\
\text { ють перевагу перед друкованими, що } \\
\text { сприяє зростанню конкурентоспромож- } \\
\text { ності товару }\end{array}$ \\
\hline $\begin{array}{l}\text { Чисельність користу- } \\
\text { вачів мережі Інтернет в } \\
\text { Україні }\end{array}$ & 3 & Зростає кількість потенційних споживачів \\
\hline $\begin{array}{l}\text { Чисельність покупців } \\
\text { електронних магазинів в } \\
\text { Україні }\end{array}$ & 3 & $\begin{array}{l}\text { Користувачі мережі Інтернет привчаються } \\
\text { до користування електронними магазина- } \\
\text { ми, в тому числі і «Bookland.net.ua» }\end{array}$ \\
\hline $\begin{array}{l}\text { Чисельність користу- } \\
\text { вачів електронними ви- } \\
\text { даннями в Україні }\end{array}$ & 3 & $\begin{array}{l}\text { Зростає кількість людей, яка оцінила пе- } \\
\text { реваги електронних видань, тому у них } \\
\text { з'являється потреба купувати цей товар }\end{array}$ \\
\hline $\begin{array}{l}\text { Традиція читання елек- } \\
\text { тронних видань }\end{array}$ & 3 & $\begin{array}{l}\text { Зростає кількість людей, яка оцінила пе- } \\
\text { реваги електронних видань, тому з'яв- } \\
\text { ляється традиція читання електронних ви- } \\
\text { дань }\end{array}$ \\
\hline $\begin{array}{l}\text { Рівень технічного забез- } \\
\text { печення населення }\end{array}$ & 2 & $\begin{array}{l}\text { Розмаїття засобів для читання електрон- } \\
\text { них видань сприяє їх поширенню }\end{array}$ \\
\hline
\end{tabular}


Закінчення табл. 2

\begin{tabular}{|c|c|c|}
\hline Фактори & $\begin{array}{c}\text { Ступінь впли- } \\
\text { ву фактора на } \\
\text { підприємство, } \\
\text { бали }\end{array}$ & $\begin{array}{c}\text { Можливі варіанти відповідних дій } \\
\text { підприємства }\end{array}$ \\
\hline $\begin{array}{l}\text { Використання сировини } \\
\text { для виготовлення елек- } \\
\text { тронного видання }\end{array}$ & 2 & $\begin{array}{l}\text { Екологічні аспекти є дуже важливими, в } \\
\text { тому числі і в сприйнятті споживачем то- } \\
\text { вару }\end{array}$ \\
\hline $\begin{array}{l}\text { Забруднення навколиш- } \\
\text { нього середовища }\end{array}$ & 1 & $\begin{array}{l}\text { Екологічні аспекти є дуже важливими, в } \\
\text { тому числі і в сприйнятті споживачем то- } \\
\text { вару }\end{array}$ \\
\hline $\begin{array}{l}\text { Стан законодавчих (нор- } \\
\text { мативних) актів, які виз- } \\
\text { начають поняття «елек- } \\
\text { тронне видання» }\end{array}$ & 1 & $\begin{array}{l}\text { Наявні стандарти, що визначають особли- } \\
\text { вості та вимоги до оформлення електрон- } \\
\text { них видань }\end{array}$ \\
\hline $\begin{array}{l}\text { Стан законодавчих актів, } \\
\text { які регулюють електрон- } \\
\text { ну комерцію }\end{array}$ & 1 & $\begin{array}{l}\text { Відсутність спеціальних законодавчих } \\
\text { актів дають змогу компанії працювати як } \\
\text { звичайному торговельному підприємству }\end{array}$ \\
\hline \multicolumn{3}{|c|}{ Загрози } \\
\hline $\begin{array}{l}\text { Вартість пристроїв для } \\
\text { читання електронних } \\
\text { Книг }\end{array}$ & 2 & $\begin{array}{l}\text { Поширення електронних видань різних } \\
\text { Форматів дає користувачу вибір при- } \\
\text { строю, з якого їх читати }\end{array}$ \\
\hline $\begin{array}{l}\text { Рівень податкових ста- } \\
\text { вок }\end{array}$ & 2 & $\begin{array}{l}\text { «Bookland.net.ua» входить у ТОВ і є плат- } \\
\text { ником податків на загальних умовах }\end{array}$ \\
\hline $\begin{array}{l}\text { Рівень доходів населен- } \\
\text { ня }\end{array}$ & 2 & $\begin{array}{l}\text { Нижча вартість електронного видання у } \\
\text { порівнянні із традиційним аналогом ро- } \\
\text { бить даний вид товару доступнішим }\end{array}$ \\
\hline $\begin{array}{l}\text { Рівень політичної } \\
\text { стабільності }\end{array}$ & 2 & $\begin{array}{l}\text { Реалізація електронних видань не має } \\
\text { географічних обмежень, тому реалізація } \\
\text { можлива не тільки в Україні, а й у всіх } \\
\text { країнах світу }\end{array}$ \\
\hline Рівень читання в Україні & 2 & $\begin{array}{l}\text { Популяризація електронних видань, мож- } \\
\text { ливо, підвищить рівень читання в Україні }\end{array}$ \\
\hline $\begin{array}{l}\text { Рівень інформатизації } \\
\text { суспільства }\end{array}$ & 2 & $\begin{array}{l}\text { Реалізація електронних видань не має } \\
\text { географічних обмежень, тому реалізація } \\
\text { можлива не тільки в Україні, а й у всіх } \\
\text { країнах світу }\end{array}$ \\
\hline
\end{tabular}

Аналіз безпосереднього оточення підприємства передбачає аналіз тих факторів зовнішнього середовища, з якими підприємство знаходиться в безпосередній взаємодії. У стратегічному аналізі пріоритетними факторами мікросередовища $є$ споживачі, конку- ренти і постачальники. На основі SWOT-аналізу діяльності компанії «Bookland. net.ua» було визначено сильні і слабкі сторони її комерційної спеціалізації та вказано можливості і загрози для розвитку торгівлі електронним книжковим контентом в Україні. 


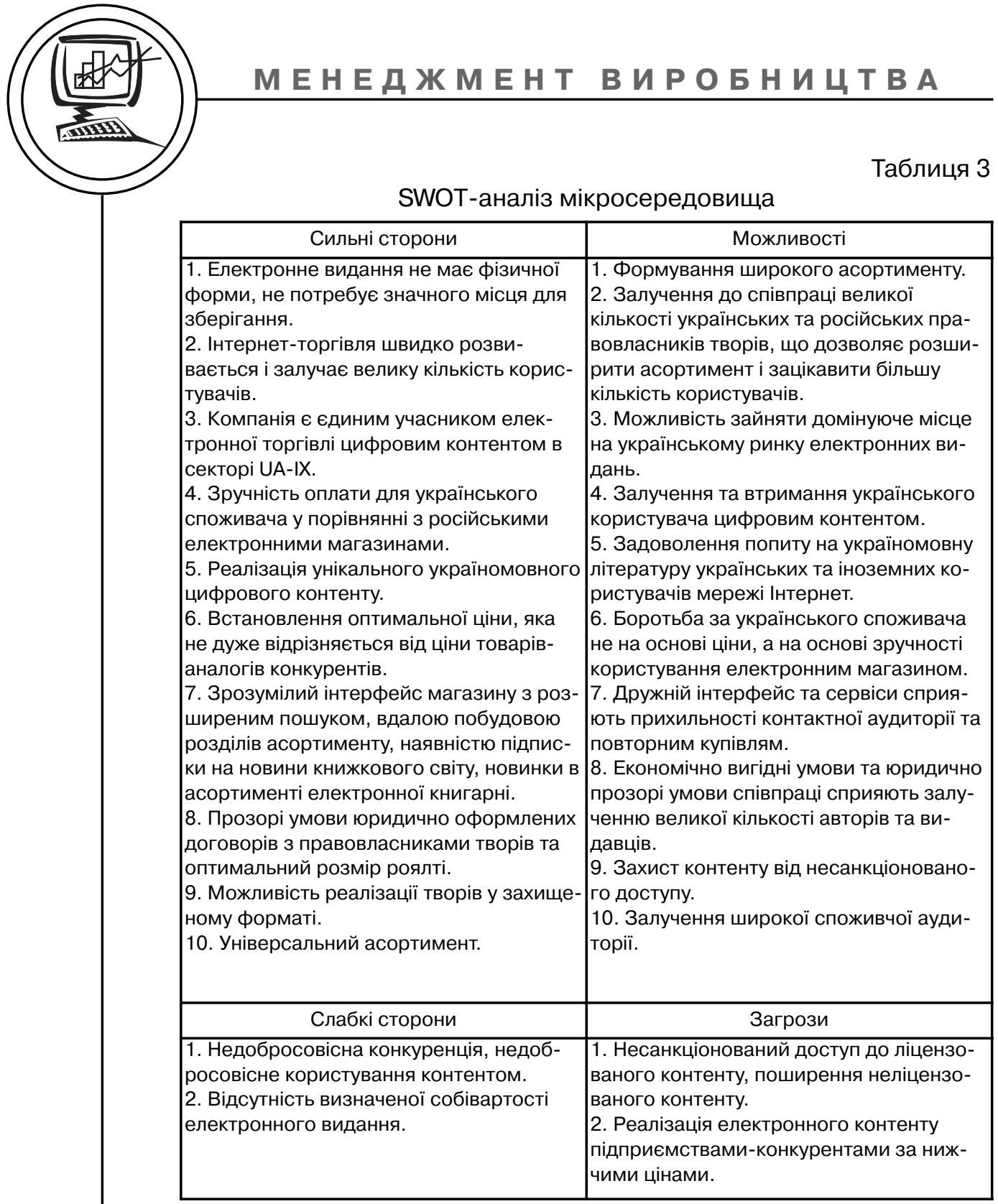

Можливі варіанти дій підприємства з метою запобіганням ризиків у мікросередовищі:

- укладання договорів 3 авторами (правовласниками) про ексклюзивність поширення контенту;

- реалізація електронних видань у захищених форматах;

- зазначення в договорі із авторами про заборону розміщен- ня текстів у мережі Інтернет у вільному доступі;

- відслідковування та по можливості перешкоджання поширенню неліцензованого контенту;

- постійний моніторинг цінової та асортиментної політики основних магазинів-конкурентів з метою підтримання цінової конкурентоспроможності, 
впровадження різноманітних маркетингових заходів зі стимулювання збуту тощо.

\section{Висновки}

Аналіз макро- і мікросередовища свідчить про значні і реальні перспективи реалізації електронних книг в Україні. Постійне зростання рівня інформатизації українського суспільства надає технічну можливість значній частині населення України долучитись до світу інформаційних технологій, оцінити переваги електронних видань та способу їх придбання. Вважається, що популяризація електронних видань зможе підвищити рівень читання в Україні завдяки зручностям цифрових тех- нологій та впливу економічного фактору. Найбільшою загрозою $€$ менталітет населення, тобто небажання платити на продукт, який поширюється мережевим способом, постійні спроби зламати захищений продукт та розповсюдити незахищені копії електронних видань. Крім того, розглядаючи конкурентоспроможність електронних книжкових магазинів, які реалізують цифрові видання (контент), варто зазначити, що для мережі Інтернет відсутні географічний і часовий фактори, тому головною перевагою електронного магазину є асортимент (універсальний чи спеціалізований), способи оплати, зручність інтерфейсу та цінова політика.

1. Барышева О. В. С Книга в паутине [Текст] / Л. Барышева, Р. С. Гиляревский. - М. : НТИ-Компакт, 2003. - 304 с. 2. Василенко Г. А. Электронная книга: pro I contra: вгляд из Интернета [Текст] / А. Г. Василенко, Р. С. Гиляревский // НТИ. Сер. 1. Орг. и методика информ. работы. - 2001. - № 4. - С. 14-23. 3. Электронный документ: создание и использование в публичных библиотеках [Текст] / под ред. Р. С. Гиляревского, Г. Ф. Гордукаловой. - СПб. : Профессия, 2007. - 664 с. 4. Земсков А. И. Электронная информация и электронные ресурсы [Текст] // А. И. Земсков, Я. Шрайберг. М. : Изд-во «Фаир», 2007. - 528 с. 5 . Земсков А. И. Электронные библиотеки [Текст]: учеб для студентов ВУЗов культуры и искусств и др. высших учеб. заведений / А. И. Земсков, Я. Шрайберг. - М.: Либерия, 2003. - 352 с. 6. Воройский Ф. С. Систематизированный толковый словарь по информатике [Текст] / Ф. С. Воройский. - М. : Либерия, 1998. - 376 с. 7. Кушнаренко Н. Н. Документоведение [Текст] / Н. Н. Кушнаренко. - 7-е изд., стереотип. - К. : Знання, 2006. - 459 с. Антопольский А. Б. Информационные ресурсы России [Текст] : науч-метод. пособие / А. Б. Антопольский. - М. : Либерия, 2004. - 421 с. 8. Беловицкая А. О. Информация и книга [Текст] / А. А. Беловицкая // Наука о книге: Традиции и инновации: материалы 12-й Междунар. науч. конф. по пробл. книговедения: Москва, 28-30 апреля 2009 г. : в 4-х ч. - М., 2009. - С. 215-219. 9. Швецова-Водка Г. М. Документознавство [Текст] : навч. посіб. / Г. М. Швецова-Водка. - К. : Знання, 2007. - 400 с. 10. Антопольский А. Б. Информационные ресурсы России [Текст] : науч-метод. пособие / А. Б. Антопольский. - М. : Либерия, 2004. - 421 с. 11. Бушуев С. В. Электрона и традиционная книга в информационном обществе [Текст] / С. В. Бушуев // Девятая Международная научная конференция по проблемам книговедения «Книга и книжное дело на рубе- 


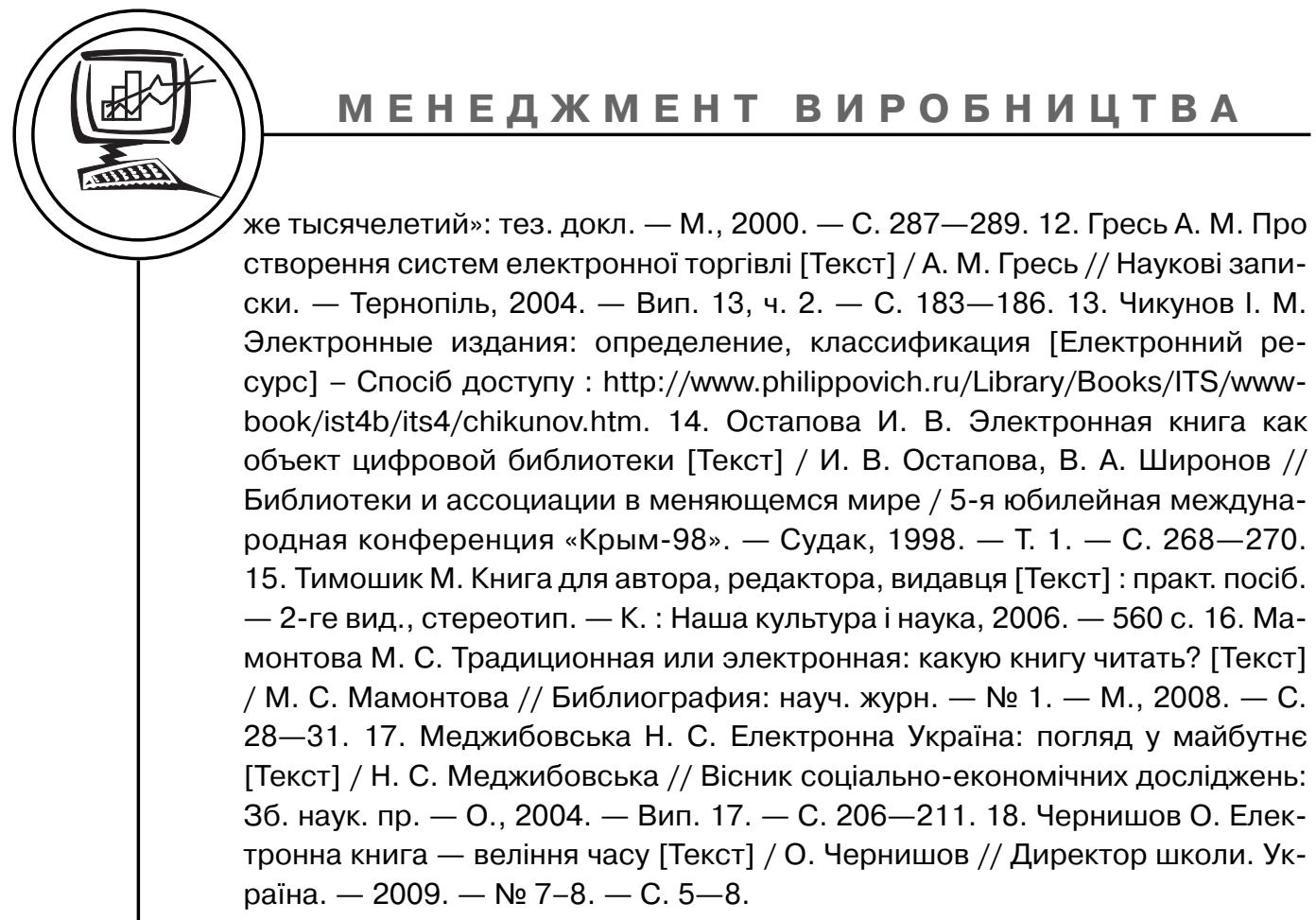

Рецензент - А. В. Кваско, к.е.н., доцент, НТУУ «КПІ»

Надійшла до редакції 13.05.11 